\title{
Map of Maryland and Virginia of 1660-1670 Created by Augustin Herrmann
}

\author{
John R. Hébert ${ }^{1}$, Jan T. Kozák ${ }^{2}$ \\ ${ }^{1}$ Geography and Map Division, Library of Congress, Washington DC, USA \\ ${ }^{2}$ Institute of Geophysics, Prague, Czech Republic \\ Email:kozak@ig.cas.cz
}

Received November 16, 2011; revised December 28, 2011; accepted January 20, 2012

\begin{abstract}
In the paper a little known large 4-folio map of the territory of the later US states Virginia and Maryland is introduced. The map, which was surveyed and composed between 1660 and 1670, is exceptional from several points of view: the vast impenetrable territory covering a strip of land of about $700 \times 400 \mathrm{~km}$ was mapped by one man, Augustin Herrman "Bohemian" (as he called himself) and by his crew during 10-year surveying and trigonometric measurements. It seems that this extraordinary map belongs among the first geodetically surveyed maps of the American territory. In 1960 altogether 5 copies of the map, complete in four parts, were known in British, French and American Libraries and map collections.
\end{abstract}

Keywords: Historical Cartography; Augustin Herrmann; Trig Station Surveying; Maryland; Virginia

\section{Introductory Remarks}

Augustin Herrman (1623-1686) born in Bohemia, i.e., in the western half of the present Czech Republic, no doubt played an exceptional role in colonial America in the 1640s-1680s when the first Dutch and English settlers came to the East coast of North America.

Just a few years before Herrmann's birth the flames of the Thirty Year War blazed up in Central Europe. That was the war in which Roman Catholic regiments led by the Hapsburg imperial family and groups of protestant armies of North and West Europe engaged in an endless contest. Since Augustin Herrman (Heřman in Czech) came from a Protestant family, his father was an evangelic pastor, his family, similarly as the other Protestants in violently re-Catholicized Bohemia, suffered under a Catholic-oriented persecution. Many endangered families searched for tolerant exile in protestant Germany, England and in the Netherlands; that was also the lot of Herrman's family, which left Prague for Zittau in Upper Lusatia and from there the Herrmans continued to the Netherlands where they multiplied the crowds of religious exile immigrants. There young Augustin spent childhood and school years and received common \& specialized education in geometry, mathematics, surveying, painting, languages, as his later graphical and surveying achievements confirm. Augustin also widened his language knowledge in that pre-American period: besides German, Dutch and Czech languages he acquired also English and Latin. He traveled much in his teenage years.
He visited London, German countries, Bohemia in 1640 and repeatedly the West Indies and the North America, as an assistant and later factor of the West Indian Society or as a business officer of the Pieter Gabry trading house in Amsterdam.

\section{America-New Amsterdam-Maryland}

By the year 1644 Augustin entered a decisive period of his life. He moved definitively to America, which became his new and last home. Quite naturally, his destination in the New World was Nieuw Amsterdam, New Amsterdam (later New York) in the territory named Nieuw Neederlands controlled by the Dutch West Indian Society. A sketch of New Amsterdam created by Herrman around 1650 is shown in Figure 1. For the self-portrait of August Herrman see Figure 2.

In Nieuw Amsterdam Herrman became a regular member of local Dutch colony. In the middle of the $17^{\text {th }}$ century Augustin traded and speculated with land tracts, not only, in the region of New Amsterdam, but also, in today New Jersey, in New Amstel on the Delaware River, and, later, in the English colonies in the northern part of today's New York state, along the Connecticut River, in Virginia, Pennsylvania and in Maryland.

During the time he owned large land holdings, Augustin experimented with planting of indigo in the territory of present New York City. Here we may speculate whether it was Augustin Herrman and his indigo plantations, who brought blue indigo color to America, the 


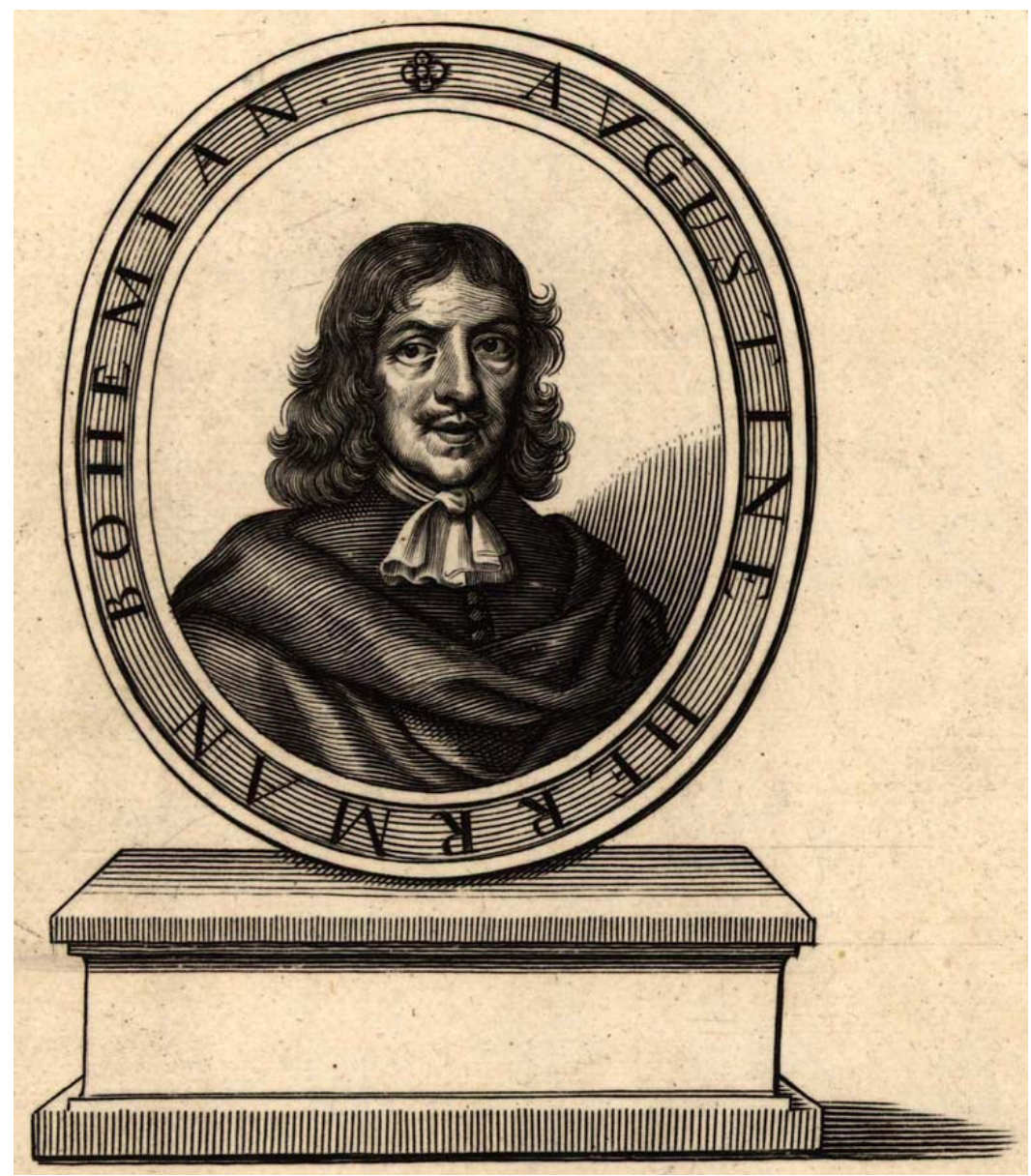

Figure 1. Self portrayal of Augustin Herrman. Copper engraving decorating his map of Maryland and Virginia of 1660-1670, see also Figure 3.

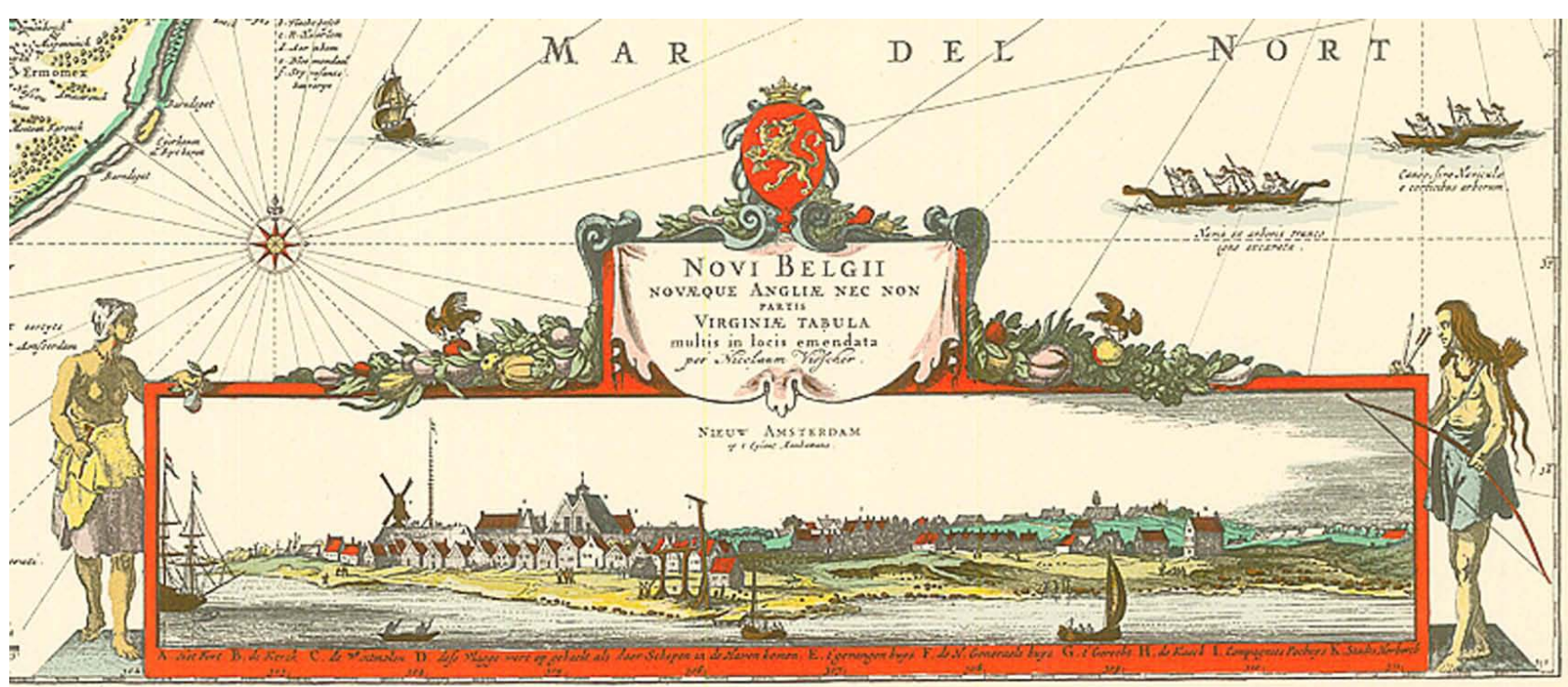

Figure 2. Vedute of Nieuw Amsterdam (present New York). Copper engraving made after model depiction created allegedly by Augustin Herrman in 1650. A. Herrman's drawing was later taken by Dutch map-maker Nicolaus Visscher in Amsterdam, who used the vedute for decoration of his map of NE coast of colonial America. Visscher's map entitled Belgia Nova was repeatedly published in 1660s and 1670s. 
color which later decorated cotton dresses of the country population.

The arrival of the new Governor of the New Netherlands, Peter Stuyvesant, in New Amsterdam in May 1647 shaped dramatically the fate of young Augustin. The new Governor soon recognized Augustin's wide abilities and fast logical thinking and appreciated his education, knowledge of languages and, especially, his ability to perform successfully complex, delicate negotiations in controversial diplomatic talks with representatives of neighboring English colonies. Augustin's star rose rapidly. Soon, by September 1647, Stuyvesant confirmed Augustin Herrman as a member of the elected Assembly of Advisers, the socalled Council of Nine.

In the year 1651 Augustin married young Janneke Verlet, one of nine children of Amsterdam furrier Caspar Verlet who came with his family from the Netherlands to New Amsterdam in 1650. Augustin Herrman had 5 children with Janneke; they were the first son, baptized Ephraim Georgius (1652-1689), the second son, baptized Casparus (1656-1697), and the daughters baptized Anna Margareta (1658-1729), Judith (1660-1761!) and Francina (1662-?).

The sons had in all three male descendents of whom only one, Casparus' son, later Colonel Ephraim Augustin, reached the age of adulthood. The two sons of Colonel Ephraim Augustin died in boyhood and Herrman's family name vanished after that. The descendents of Augustin's daughters, on the other hand, were numerous and shared considerably in the formation of aristocratic families of colonial America.

The years 1659-1660 can be classified as a milestone in the life of Augustin Herrman. Let us cite [1]: "In September 1659 Augustin Herrman and his neighbor Resolverd Waldron were entitled to make an important diplomatic mission to Maryland's Governor Josias Fendall concerning mutual repatriation of escaped servants and slaves. The main topic of the debate was focused on (for Dutch side) unacceptable requirements and threats of the English Colonel Nathaniel Utie on the Delaware River". During negotiations both the sides stuck to their positions; however, between Augustin and Philip Calvert, future Governor of Maryland, a friendly relationship was established, which proved shortly to be important for Augustin.

Most probably, in that time, the desirability of an updated map of the region emerged in a written form: Augustin, in his report of October 1659, to Pieter Stuyvesant, the Governor of the New Netherlands, formulated a proposal to create an "exact" map of the debated region, i.e., Maryland, Virginia, Delaware and parts of New Jersey. The governor, however, did not reply quickly to Herrman's proposal.

On the other hand, the same proposal, which Herrman later addressed to Maryland Governor Philip Calvert was eagerly accepted, and, in addition, Herrman was promised a large tract of land at the mouth of the Susquehanna River where it enters the Chesapeake Bay as compensation for the cost of creating the map.

Such action by Herrman, no wonder, was considered by the New Amsterdam governor and his people as a treasonous act on Augustin's part. As a firm answer from Governor Stuyvesant, should we like to be ironical, there awaited Augustin after his return to New Amsterdam, a series of writs against him demanding his payment of his debts towards the members of the Dutch colony. Augustin's mind, however, was already fixed towards his new dream, towards his new home in the Cecil County in Maryland.

As an advance payment for his future map of Virginia and Maryland, Augustin received from Governor Calvert the Decree of denizen on January 14, 1661, which entitled him to keep the land in Maryland. The first tract of land, a 4000 acre plot, was surveyed for him and submitted to him on June 3, 1661. Eventually, the foundation of long-desired Bohemia Manor was laid in Cecil County.

In 1661 Augustin completed construction of the first stone house in his Manor; afterwards he laid the foundations for other settlements: Little Bohemia, Bohemia Mills, Three Bohemia Sisters, Port Herrman, Hack Point and St. Augustine Manor.

The original size of the Manor, the 4000-acres plot, was, especially after completing the last sheet of the promised map in 1670, constantly enlarged up to the year 1681 , in which it reached 16.439 acres, which is equal to ca $66.52 \mathrm{~km}^{2}$.

A question may be raised as to why Augustin, considering all his adventures (but also regardless of all the achievements) in New Amsterdam, decided after 17 years to leave New Amsterdam definitively. Should the roots of his decision be based in repulsive court money squabbling, unfair accusations and denigrations or to impediments placed before him? Or did he, primarily, love his vision of his new independent kingdom?

Yes, both these reasons were important. However, there might be also another and that was Augustin's calculation. He had kept well informed about the situation in neighboring English colonies. And he became aware of the dynamics of their demographic, economical and other forms of advancement. Had he presumed correctly the indefensible position of the stagnating, relatively small Dutch colony and its forthcoming absorption by the English? As a matter of fact only three years after Augustin's departure of New Amsterdam, the town with whole the land around it, were taken by the English forces in 1664 .

When founding his Manor Herrman strived for the right of automatic transfer of his hereditary title to his 
eldest son. Reaching this right was conditioned by awarding him a title of Court Baron, namely Court Baron on Bohemia Manor. This title and all the rights associated with it were granted to him, including his Coat of Arms.

In the years 1679-1684 Augustin had to face concentrated attacks led by the Labadists, an extreme protestant sect having its adherents in some Western European countries, namely in the Netherlands and in England. The sect's envoy-members visited colonial territories in the tolerant New World and tried to find out a land for their specific, (in Europe not-much-welcomed) denomination. Unfortunately for Herrman, they discovered a way to Bohemia Manor. Finally, they dragged the land out of Augustin's Bohemia Manor, an area of 3750 acres. Since 1675 Bohemia Manor was frequently visited also by the Quakers of William Potter. They urged Herrman to declare officially his subordination to Penn's administration.

On November 11, 1686, Augustin Herrman, disappointed by conversion of his first-born son and titular heir Ephraim to Labadistic confession (Augustin finally rejected Ephraim and anathematized him) and disgusted by bickering with the Labadists for his own land, died in the age of 63 years. In form of a novel Herrman's dramatical and adventurous life is described in [1].

\section{The Map}

What was the map which Augustin created? He began to conduct surveying work for the map in 1660. The mapped area, see Figure 3, consisted of much of current Maryland and Virginia, which the mapmaker saw from east to west (i.e., south on the left, north on the right). It was printed on four separate sheets, to be joined to form the large map. The map was situated in the global network of parallels of latitude. At the bottom margin of the map the latitude scale locates the map into a belt between southern parallel 40 degrees $05^{\prime}$ and northern parallel 46 degrees 20'. From north to south the map covers a belt of $6 \frac{1}{4}$ degrees what corresponds to $694 \mathrm{~km}$.

The first part of the map, i.e. its right bottom segment, was completed quickly by Augustin. It was that portion of his large map that included the area that he had obtained (a portion of Cecil County) and therefore he was most familiar with its relief and culture. For mapping the rest of the vast territory in question, Herrman needed ten years to complete, during which time he organized long series of survey expeditions into those distant parts of land, mostly virgin forests, without many conveniences of byways or paths. He completed the map in 1670 .

According to $\mathrm{Ch}$. J. Schewe, historian of the Baltimore County, Maryland, "Herrman, in order to collect necessary data for his map, had to perform repeatedly survey expeditions. The coast line of Maryland itself has the length of some 3000 miles [ca $4800 \mathrm{~km}$ ]. By adding to it the length of Virginia and Delaware coasts we get an idea what distances he had to examine... He had to be out of home for weeks, perhaps for months. According to his splendid map, which he created, he had to have the best geodetic devices of the time at his disposal: surveying chains, quadrant, surveying compass. In the survey expeditions Herrman had to be assisted by his rodmen and other helpers, by guide, bargeman, interpreter, body guard, cook..."

In the final version of the map the large title V I R G I $\mathrm{N}$ I A covered the upper, i.e., western half of the map. The second inscription M A R Y L A N D denoted the right, i.e., northern half of the map. Another map title, Virginia and Maryland is repeated in the decorative cartouche which is shaped as a stony memorial decorated by Herrman's coat of arms on its top and by two Indian figures on its sides. The map legend is given in the memorial's fundament.

A large British coat of arms with a lion and traditional unicorn dominates the map in its upper central part, being accompanied by smaller escutcheon of Baltimore located right of it. Part of the map, near to the area of Bohemia Manor, is decorated by the mapmaker's selfportrait. Additionally, ten more detailed informative remarks are engraved into the map, e.g., on local geography, on Indian settlements, on water depths and sandy shallows in coastal regions, on farms of settlers and on their plantations. The images of three large sailing ships and an Indian canoe animate the map's coastal waters.

The map, according to the original model-drawings, was engraved into four folio size copper plates, which were, prepared by William Faithorne, the London engraver, in between 1670-1673. However, "Augustin was not content with the engraver's work: “... the map was unperfected by engraver Faithorne who defiled the print by numerous mistakes". The map editor the Hydrographer of the King, John Seller in London is stated.

The map was printed in a scale $1: 720,000$, size $31 \times 36$ inches, what corresponds to ca $79 \times 91.5 \mathrm{~cm}$. It is divided into 4 separate folio-size paper sheets which altogether make one whole. The large map-scale, on one hand, enabled Herrman to create a detailed cartographical portrayal of large area. On the other hand, the resulting map of large dimensions should be cut into four segments for printing purposes.

It seems, however, that even this "cutting" of the large map did not help much in resolving its practical and/or frequent use if we consider that the marginal zones that linked mutually all four map segments passed through the centre of the mapped colonies. Moreover, if the user/ owner wished to join neighboring segments, he had to cut out at least one strip of paper margin, or to fold it.

We do not know how many map copies were printed by John Seller. However we do not presume that the series was large. This is in agreement with the following 


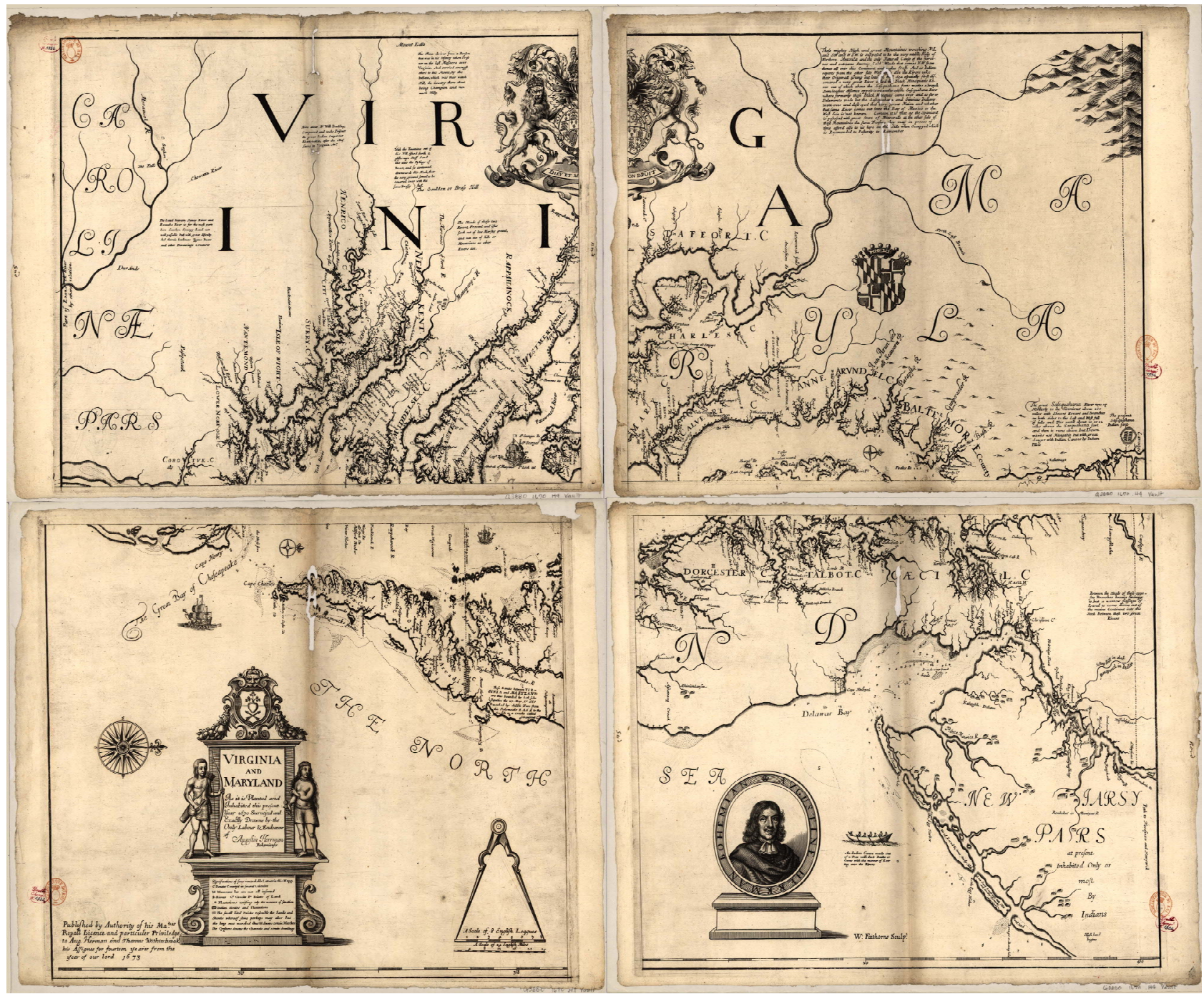

Figure 3. Map of Virginia and Maryland surveyed and plotted by Augustin Herrman in the years 1660-1670. Four-folio size black-and-white copper engraving was published in London in 1673. Five complete series of the map are known in the USA, UK and in France. Here reproduced copy is kept in the Map Collection, Geography and Map Division, Library of Congress, Washington DC, USA.

recorded detail: when two Labadistic envoys, Danckaerts and Sluyter returned from America to London in 1680, (not quite 10 years since the map appeared), they wished to buy the map in London, but it was not longer available.

The reader may be interested in how many copies of Herrman map survived up to our time. According to M. Zeleny altogether five copies of the map (each complete in 4 parts) are known. One was located in the Granville Collection, in the British Library. The second copy, together with the manuscript draft, was located in the John Carter Brown Library in Providence, (Rhode Island, USA); it was presented to the Library by William Blath- wayt in 1929. Two other copies were located in Bibliothèque National in Paris. The fifth copy (obtained from Paris by exchange in 1960) is located in Washington, in the Library of Congress, in the Geography and Map Division. The Washington map copy is reproduced in this paper as Figure 3.

\section{REFERENCE}

[1] J. Koudelka, "Pán na České Řece," Jaroslav Salivar, Prague, 1946. 